\title{
Contribution Towards the Anatomy of the Esophageal Hiatus and its Relationship with the Presence of Bundles of Collagen Fibers in its Margins
}

\author{
Contribución a la Anatomía del Hiato Esofágico y su Relación \\ con la Presencia de Haces de Fibras Colágenas en sus Márgenes \\ "José Jeová de Oliveira Filho; ***Benedito Herani Filho; ${ }^{* * *}$ Francisco Prado Reis; \\ ${ }^{* * * * *}$ Vera Lúcia Correa Feitosa \& ${ }^{* * * * * *}$ José Aderval Aragão
}

FILHO, J. J. O.; FILHO, B. H.; REIS, F. P.; FEITOSA, V. L. C. \& ARAGÂO, J. A. Contribution towards the anatomy of the esophageal hiatus and its relationship with the presence of bundles of collagen fibers in its margins. Int. J. Morphol., 30(3):858-865, 2012.

SUMMARY: The aim was to detect the presence of bundles of collagen fibers in the margins of the esophageal hiatus and establish if there is any relationship of these bundles with the anatomy of the hiatus. Ten adult male cadavers, with no gross anatomical alteration caused by trauma, surgery or disease, upon the esophageal hiatus were used in the study. A piece of anatomical structure comprising the diaphragm with the esophageal hiatus and adjacent tissues was removed, dissected and $10 \%$ formol embedding. With the aid of a digital caliper, measurements of the perimeter of the esophageal hiatus were done both in the abdominal and thoracic sides. For the structural study each margin was divided in six sections. Staining techniques of Masson and Picrosirius-hematoxilin were used. Collagen fibers bundles had been found in 8/10 studied cadavers, distributed in 13 margins of the hiatus, of which 7 to left and 6 to the right. The muscle fibers originating from the right pillar had participated in forming both margins of the esophageal hiatus in $60 \%$ of cadavers, while in $40 \%$, the fibers of the left pillar had formed the medial side of the right margin. The right margin was statistically thicker than the left. It did not have a correlation between the measures of the vertices of the angles superior/inferior and the transversal measure of the esophageal hiatus. The measures between the vertices of the angles superior/inferior, respectively, with the central tendon and median arcuate ligament, had presented thoracic values that tended to the double, in relation to the abdominal ones, and had been statistically significant. These distances were smaller in cadavers who possessed bundles of collagen fibers in the margins of the esophageal hiatus. Bundles of collagen fibers bundles were found in $65 \%$ of the 20 margins of the esophageal hiatus. The margins of the esophageal hiatus were predominantly formed by muscles fibers originated of the right pillar of the muscle diaphragm. The anatomical and morphometric data presented statistically significant values regarding: thickness of the right arm in relation to the left; distance between the vertex of the superior angle and the central tendon; and distance between the vertex of the inferior angle and the median arcuate ligament.

KEY WORDS: Diaphragm; Esophagogastric Junction; Collagen; Cadaver; Humans.

\section{INTRODUCTION}

The pillars of the muscle diaphragm have an essential role in anatomically delimiting the esophageal hiatus. There are disagreements about various aspects of the anatomy of the hiatus, with consequent implications for surgery at this level, especially regarding variations in the participation of these pillars in forming the hiatus and in determining its type (Costa, 1991; Cecconelo et al., 1994; Moore, 1994; Costa \& Pires-Neto, 2004). These disagreements have also occurred in relation to the terminology used to describe the involvement of these pillars in forming the hiatus (Bowden \& el-Ramli, 1967; Low, 1907).

Some authors believed that the margins of the esophageal hiatus would exclusively be formed by fiber bundles from the right pillar (Moore; Low; Cunningham, 1949; Allison, 1951; Harrington, 1955; Madden, 1956;

\footnotetext{
Assistant Professor, Medical School of Tiradentes University (UNIT), Aracaju, Sergipe, Brazil.

** Associate Professor, Department of Gastroenterology Surgery, Federal University of São Paulo (UNIFESP), São Paulo, Brazil.

**** Titular Professor, Medical School of Tiradentes University (UNIT), Aracaju, Sergipe, Brazil.

***** Associate Professor, Department of Morphology, Federal University of Sergipe.

${ }^{* * * * * *}$ Adjunct Professor of Human Anatomy, Federal University of Sergipe (UFS) and Titular Professor, Medical School of Tiradentes University (UNIT), Aracaju, Sergipe, Brazil.
} 
Botha, 1958; Marchand, 1959; Mann et al., 1964; Girgis et al., 1965; Shehata, 1966; Hamilton, 1882; Spalteholz, 1988; Basmajian, 1993). Lataste \& Sulzer (1980) and Mourot \& Bastian (1998) stated that this occurred in $95 \%$ of the cases; Juraniec (1972), 75\%; Pataro et al. (1961), 64\%; Collis (1966) and Collis et al. (1954), 46\%; and Bowden \& elRamli, 36\%.

Listerud \& Harkins (1958) described eleven types of esophageal hiatus, among which the most frequent were type A $(50 \%)$ and type B $(44 \%)$. In the type A esophageal hiatus, the two margins emerge from the right pillar, while in type B the left margin emerges from the right pillar, and the right margin emerges from both pillars of the diaphragm. Groszec (1984) described twelve types of hiatus, among which type I (58\%) as the most frequent. In this type, both two sides would arise from the right pillar, with lesser participation by the left pillar.

Botros et al. (1990) accepted that the esophageal hiatus was exclusively formed by the right pillar in $10 \%$ of the cases and the left pillar in $2 \%$ of the cases. In $62 \%$ of the cases, both pillars participated, although the right pillar predominated. In some studies, it was observed that the esophageal hiatus was formed equally from the two pillars of the muscle diaphragm in $100 \%$ of the cases (Maisonnet \& Coudane, 1950; Testut \& Latarjet, 1979; Carey \& Hollinshead, 1955; Bouchet \& Cuilleret, 1979). According to Bowden \& el-Ramli, this type of formation occurred in $32 \%$ of the cases, and according to Juraniec, in $25 \%$. Pataro et $a l$, found that the esophageal hiatus was exclusively formed by the right pillar in $41.6 \%$; by both two pillars, in $58.3 \%$ (albeit with predominance of the right pillar); and exclusively by the left pillar in only one case. Some authors (Allison; Groszec; Carey \& Hollinshead; Giordano-Lanza, 1973; Gardner et al., 1988; Khale et al., 1995) has maintained that involvement of the left pillar in the formation of the esophageal hiatus would be exceptional and would be limited to only a small increase in muscle fiber.

Some authors have accepted that the values of the craniocaudal and transverse diameters are important in the morphology of the esophageal hiatus. The craniocaudal diameter has been found to vary around $1.5 \mathrm{~cm}$ (Lataste $\&$ Sulzer; Mourot \& Bastian; Testut \& Latarjet; Dell' Isola et al., 1989; Silva, 1992; Guivarc'h, 1973; Tenière et al., 1994), whereas the transversal diameter varied around 1.2 cm (Lataste \& Sulzer; Testut \& Latarjet; Giordano-Lanza; Dell'Isola et al.; Silva).

Most authors have accepted that the structure of the esophageal hiatus is formed exclusively by muscle fiber bundles. Collis and Collis et al., accepted that variation in forming the limits of the esophageal hiatus, and differences in the presence of these fiber bundles in the anterior and posterior edges of the hiatus, could be significant in producing illnesses like hiatus hernia. Bowden \& el-Ramli accepted the possibility that large opening of the esophageal hiatus might be related to a limited tendinous origin. On the other hand, an elliptical opening might correspond to an extensive tendinous origin. This author concluded that the posterior limit of the esophageal hiatus would invariably be muscular and that the preceding limit would be tendinous. Androulakis et al. (1966) reported that collagen fibers were present at the level of the lower third of the esophageal hiatus. Other authors have described similar findings (Costa; Costa \& Pires-Neto; Gray et al.; Skandalakis et al.; Costa \& Barreto, 1986). However, these studies did not take into consideration the anatomical relationship between the esophageal hiatus and the presence of such collagen fiber bundles, with regard to delimiting this hiatus.

\section{MATERIAL AND METHOD}

Ten human cadavers of male adults without macroscopic signs of trauma, surgical intervention or illnesses of the esophageal hiatus were used. From each cadaver, a block was removed containing part of the diaphragm muscle and surrounding tissues. The blocks were dissected before and after fixation in a $10 \%$ formaldehyde solution. The dissection exposed the abdominal and thoracic faces of the esophageal hiatus, from the central tendon to the main pillars of the diaphragm. In order to adequately preserve the anatomy of the esophageal hiatus, the muscle diaphragm was affixed to a polystyrene board.

With the aid of digital calipers the following measurements were made: distance between the vertices of the superior angle (VSA) and lower angle (VIA) of the esophageal hiatus; greatest transversal distance between the internal edges of the hiatus; thickness of the pillars; distance between VSA and the tendinous center; and distance between VIA and the median arcuate ligament of the muscle diaphragm (Fig. 1).

Each of the pillars at the level of the hiatus was divided into six sections. These sections were embedded in paraffin, and histological sections of seven micrometers in thickness were made. The picrosirius, hematoxylin and Masson staining techniques were used. The statistical analyses were performed using the Origin 6.0 software, by means of Student's t test and Pearson's correlation coefficient. 


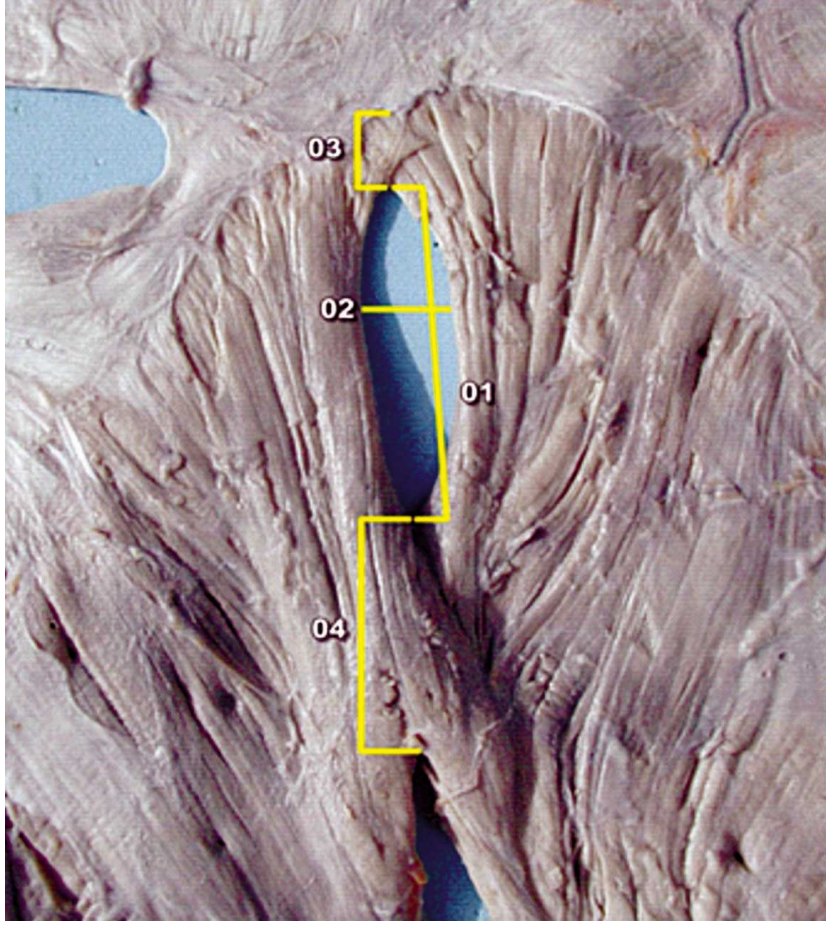

Fig. 1. Photograph showing the distances measured in the esophageal hiatus. 1. Distance between the vertices of the superior/inferior angles. 2. Greatest transversal distance of the esophageal hiatus. 3. Distance between the vertex of the superior angle and tendinous center. 4. Distance between the vertex of the inferior angle and arcuate median ligament.
In all the cadavers studied, the right pillar of the muscle diaphragm formed both the left branch and the lateral region of the right branch of the esophageal hiatus. The origin of the medial branch of the right branch was also predominantly the right pillar, but in four cases the origin of this region was the left pillar. Collagen fiber bundles of tendinous appearance (Fig. 2) were found in eight of the ten cadavers studied, distributed in 13 of the 20 branches of the esophageal hiatus: seven on the left side and six on the right side, all originating from the right pillar of the diaphragm muscle (Table I).

The length of the esophageal hiatus, measured as the distance between VSA and VIA, presented an average value of $4 \mathrm{~cm}$, with only three occurrences below this average. Since the width of the esophageal hiatus corresponded to the greatest lateral (transversal) distance between its branches, the values were more evenly distributed: half of them below and half of them above the average (Table II). The correlation between length and width of the hiatus was low (Fig. 3).

There was significant variation $(\mathrm{p}=0.01)$ in thickness between the left and right margins of the esophageal hiatus. In six cadavers, the right margin was thicker than the left, while in four, the margins had similar thicknesses (Table III).

Regarding the distance between VSA and the central tendon of the diaphragm muscle, the values in the thoracic face were twice as high as in the abdominal face. This difference was statistically significant $(\mathrm{p}=0.01)$. In cases

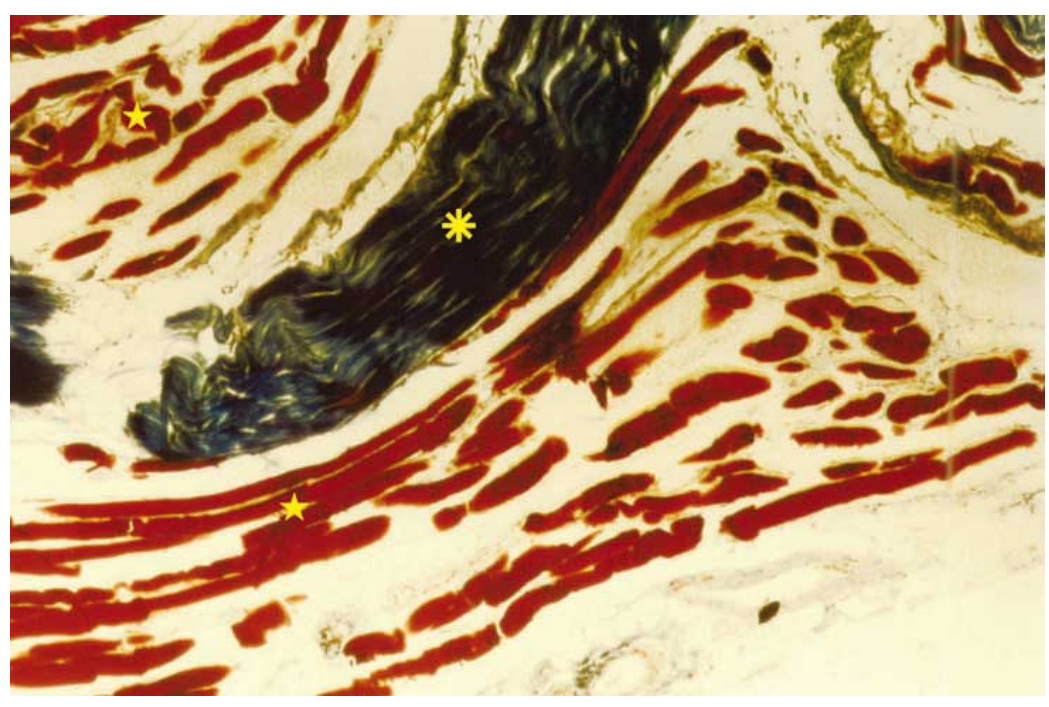

Fig. 2. Photomicrograph of a longitudinal section at the superior level of the right margin of the esophageal hiatus, showing bundles of collagen fibers (à) and muscle fibers (ê) Masson trichrome staining. 400X of esophageal hiatuses with collagen fiber bundles on their margins, the distance values were lower on both sides, while the values were higher in hiatus margins without collagen fiber bundles (Table IV).

Regarding the distance between VIA and the median arcuate ligament of the diaphragm muscle, the values were greater in the thoracic face than in the abdominal face. This finding was statistically significant $(\mathrm{p}=0.02)$, and there was a high degree of correlation between the faces $(\mathrm{r}=$ 0.82) (Fig. 4). In the cadavers in which there were collagen fiber bundles of tendinous appearance, there were two occurrences of raised values in both faces of the hiatus (Table V). 
FILHO, J. J. O.; FILHO, B. H.; REIS, F. P.; FEITOSA, V. L. C. \& ARAGÂO, J. A. Contribution towards the anatomy of the esophageal hiatus and its relationship with the presence of bundles of collagen fibers in its margins. Int. J. Morphol., 30(3):858-865, 2012.

Table I. Anatomical origin of the margins of the esophageal hiatus and its relationship with presence of collagen fiber bundles of tendinous appearance.

\begin{tabular}{|c|c|c|c|c|c|}
\hline \multirow{2}{*}{ Margins } & \multirow{2}{*}{ Region } & \multirow{2}{*}{ Pillar } & \multicolumn{2}{|c|}{ Occurrence } & \multirow{2}{*}{ Margins with collagen fiber bundles } \\
\hline & & & $\mathbf{n}$ & $\%$ & \\
\hline \multirow[t]{4}{*}{ Right } & Lateral & Right & 10 & 50 & 4 \\
\hline & & Left & - & - & - \\
\hline & Medial & Right & 06 & 30 & 2 \\
\hline & & Left & 04 & 20 & - \\
\hline Subtotal & & & 20 & 100 & 6 \\
\hline \multirow[t]{4}{*}{ Left } & Lateral & Right & 10 & 50 & 7 \\
\hline & & Left & - & - & - \\
\hline & Medial & Right & 10 & 50 & - \\
\hline & & Left & - & & - \\
\hline Subtotal & & & 20 & 100 & 7 \\
\hline Total & & & - & - & 13 \\
\hline
\end{tabular}

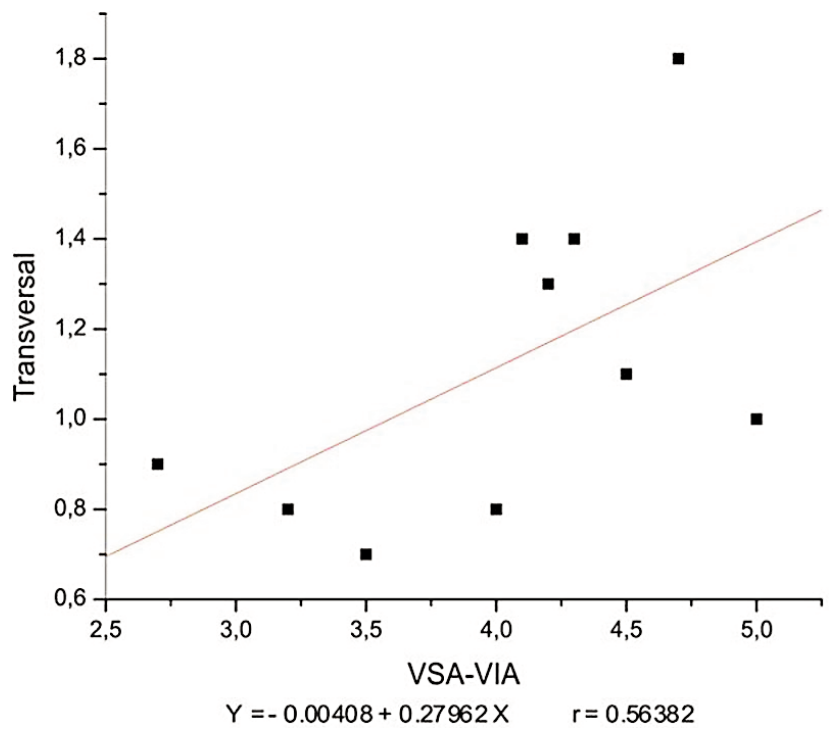

Fig. 3. Curve of correlation of Pearson enters the measure of VSAVIA versus the transversal measure.

Table II. VSA-VIA distance and transversal distance between the margins of the esophageal hiatus.

\begin{tabular}{lcc}
\multirow{2}{*}{ Cadaver } & \multicolumn{2}{c}{ Distance $(\mathbf{c m})$} \\
\cline { 2 - 3 } 1 & VSA-VIA & Transversal \\
\cline { 2 - 3 } 2 & 3.5 & 0.7 \\
3 & 4.0 & 0.8 \\
4 & 4.2 & 1.3 \\
5 & 5.0 & 1.0 \\
6 & 4.7 & 1.8 \\
7 & 4.5 & 1.1 \\
8 & 4.3 & 1.4 \\
9 & 4.1 & 1.4 \\
10 & 2.7 & 0.9 \\
Average (SD) & 3.2 & 0.8 \\
\hline
\end{tabular}

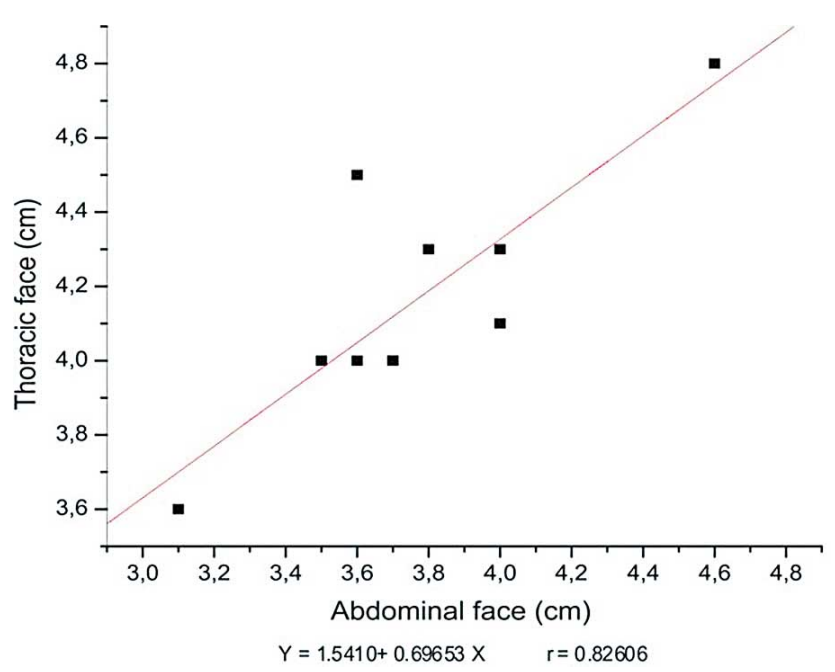

Fig. 4. Curve of correlation of Pearson enters the measures between VIA and the arcuate median ligament in the faces abdominal and thoracic.
Table III. Thickness of the margins of the esophageal hiatus.

\begin{tabular}{lcc}
\hline \multirow{2}{*}{ Cadaver } & \multicolumn{2}{c}{ Margins $(\mathbf{c m})$} \\
\cline { 2 - 3 } 1 & Right & Left \\
\cline { 2 - 3 } 2 & 0.6 & 0.6 \\
3 & 0.7 & 0.4 \\
4 & 0.7 & 0.4 \\
5 & 0.6 & 0.4 \\
6 & 0.6 & 0.4 \\
7 & 0.4 & 0.4 \\
8 & 0.6 & 0.4 \\
9 & 0.4 & 0.4 \\
10 & 0.4 & 0.4 \\
Average (SD) & 0.4 & 0.3 \\
\hline
\end{tabular}


Table IV. Distance between VSA and the tendinous center, for face of the esophageal hiatus, in all cadavers and those with bundles of collagen fiber tendinous appearance.

\begin{tabular}{lcccc}
\hline \multirow{2}{*}{ Cadaver } & \multicolumn{2}{c}{ All cadavers } & \multicolumn{2}{c}{ Cadavers with bundles collagens } \\
\cline { 2 - 5 } & \multicolumn{2}{c}{ Hiatus face $(\mathbf{c m})$} & \multicolumn{2}{c}{ Hiatus face (cm) } \\
& Abdominal & Thoracic & Abdominal & Thoracic \\
\cline { 2 - 5 } 1 & 0.40 & 1.0 & 0.40 & 1.0 \\
2 & 0.50 & 1.1 & 0.50 & 1.1 \\
3 & 0.70 & 1.4 & - & - \\
4 & 0.30 & 0.8 & 0.30 & 0.8 \\
5 & 0.50 & 1.0 & 0.50 & 1.0 \\
6 & 0.40 & 0.9 & 0.40 & 0.9 \\
7 & 1.00 & 1.2 & 1.00 & 1.2 \\
8 & 0.50 & 1.1 & 0.50 & 1.1 \\
9 & 0.30 & 1.4 & 0.30 & - \\
10 & 0.70 & 1.4 & - & 1.4 \\
Average (SD) & $0.53 \pm 0.216$ & $1.13 \pm 0.216$ & $0.48 \pm 0.223$ & $1.06 \pm 0.184$ \\
\hline
\end{tabular}

Table V. Distance between the VIA and the arcuate median ligament of the diaphragm, for face of the ligament, in all individuals and those with bundles collagen fibers.

\begin{tabular}{lcccc}
\hline \multirow{2}{*}{ Cadaver } & \multicolumn{2}{c}{ All cadavers } & \multicolumn{2}{c}{ Cadavers with collagens fibers } \\
\cline { 2 - 5 } & \multicolumn{2}{c}{ Hiatus face (cm) } & \multicolumn{2}{c}{ Hiatus face (cm) } \\
& Abdominal & Thoracic & Abdominal & Thoracic \\
\cline { 2 - 5 } 1 & 4.00 & 4.10 & 4.00 & 4.10 \\
2 & 3.70 & 4.00 & 3.70 & 4.00 \\
3 & 3.80 & 4.30 & - & - \\
4 & 3.50 & 4.00 & 3.50 & 4.00 \\
5 & 4.00 & 4.30 & 4.00 & 4.30 \\
6 & 3.60 & 4.50 & 3.60 & 4.50 \\
7 & 3.10 & 3.60 & 3.10 & 3.60 \\
8 & 3.60 & 4.00 & 3.60 & 4.00 \\
9 & 3.70 & 4.00 & 3.70 & 4.00 \\
10 & 4.60 & 4.80 & - & - \\
Average (SD) & $3.76 \pm 0.392$ & $4.16 \pm 0.330$ & $3.65 \pm 0.287$ & $4.06 \pm 0.261$ \\
\hline
\end{tabular}

\section{DISCUSSION}

There has been much controversy between different authors' findings concerning the anatomy and morphofunctional aspects of the esophageal hiatus. In the present study, $60 \%$ of the left and right margins of the esophageal hiatus originated from the right pillar of the diaphragm, while the left pillar only participated in $40 \%$. In similar studies, Listerud \& Harkins and Groszec found values of $50 \%$ and $40.8 \%$ respectively. Low participation by the left pillar in forming the margins of the esophageal hiatus has been reported by several authors (Cecconelo $e t$ al.; Allison; Groszec; Carey \& Hollinshead; GiordanoLanza; Guivarc'h).

Most authors accept that the structure of the margins of the esophageal hiatus is formed exclusively by muscle fiber bundles. In the present study, collagen fiber bundles were found in $65 \%$ of the margins of the esophageal hiatus, and all of these originated from the right pillar of the diaphragm. Androulakis et al., Gray et al., Skandalakis et al., Costa and Costa \& Pires-Neto reported similar findings, although they did not determine the number of margins of the hiatus in which collagen fiber bundles were present. Nor did they establish any correlation between their findings and the anatomical characteristics of the esophageal hiatus.

Most studies have assumed that the right margin of the esophageal hiatus is thicker than the left margin (Allison; Pataro et al.; Carey \& Hollinshead; Khale et al.). On the other hand, Lataste \& Sulzer found that the left 
margin was thicker. In the present study, the right margin of the hiatus was predominantly thicker, but in $40 \%$ of the cases the two sides had similar thicknesses. This finding seems to be uncommon in the literature. The presence of collagen fiber bundles seemed to influence the thickness of the margins of the esophageal hiatus. Thus, $66 \%$ of the hiatus margins presented above-average thicknesses. Meanwhile, the margins without collagen fiber bundles were thinner.

Bowden \& el-Ramli correlated the thickness of the lower right margin with a possible further opening of the esophageal hiatus. In the present study, four cadavers had below-average margin thickness, while in two cadavers, the lengths and widths were greater than or equal to the respective averages. The average lengths and widths of the margins were found to be roughly similar to those reported by some other authors (Lataste \& Sulzer; Testut \& Latarjet; Dell'Isola et al.; Silva). However, the correlation between these variables was statistically low.

Regarding the relationship between the anatomical esophageal hiatus and the tendinous center, some authors (Allison; Marchand; Pataro et al.) have assumed that variations in the degree of overlap of the diaphragm muscle fibers can produce differences in measurements between the hiatus and the tendinous center. According to other authors (Moore; Testut \& Latarjet; Bouchet \& Cuilleret;
Skandalakis et al.), the shape of the hemidiaphragm and the oblique position of the esophageal hiatus could also change this relationship. In the present study, this relationship was represented by the distance between the VSA and the tendinous center, and the values in the thoracic face were twice the values in the abdominal face. These values were smaller when the margins that formed the esophageal hiatus structure contained collagen fiber bundles, and were larger in the margins without collagen fibers.

Botha accepted that the distance between VIA and the median arcuate ligament would diminish with increasing age of the individual and that there would be a widening of the esophageal hiatus. The values found for the distance on the face were higher than those of the thoracic abdominal face, with a statistically significant high degree of correlation.

\section{CONCLUSION}

The presence of collagen fiber bundles in the muscle structure that delimits the margins of the esophageal hiatus seems to modify some anatomical aspects of the hiatus. It is desirable to continue to investigate this subject in order to contribute towards knowledge of the physiopathology and related surgical characteristics of this region.

FILHO, J. J. O.; FILHO, B. H.; REIS, F. P.; FEITOSA, V. L. C. \& ARAGÂO, J. A. Contribución a la anatomía del hiato esofágico y su relación con la presencia de haces de fibras colágenas en sus márgenes. Int. J. Morphol., 30(3):858-865, 2012.

RESUMEN: El objetivo fue detectar la presencia de haces de fibras de colágeno en los márgenes del hiato esofágico y establecer si existe relación de éstos con la anatomía del hiato. Fueron utilizados 10 cadáveres de individuos adultos de sexo masculino, sin alteraciones anatómicas evidentes causadas por trauma, cirugía o enfermedad, sobre el hiato esofágico. Fue retirada y disecada una sección anatómica que contendía el diafragma con el hiato esofágico y los tejidos adyacentes y luego fijada en formol 10\%. Las medidas del perímetro del hiato esofágico se realizaron con ayuda de un caliper digital en los lados abdominal y torácico. Para el estudio estructural cada margen fue dividido en seis secciones y teñidos con Tricómico de Masson y Picrosirius-hematoxilina. En 8/10 cadáveres estudiados fueron encontrados haces de fibras colágenas, distribuidos en 13 márgenes del hiato esofágico, 7 izquierdos y 6 derechos. Las fibras musculares que originaban el pilar derecho participaron en la formación de ambos márgenes del hiato esofágico en $60 \%$ de los cadáveres, mientras que en el $40 \%$, las fibras del pilar izquierdo habían formado el lado intermedio del margen derecho. El margen derecho fue estadísticamente más grueso que el izquierdo. No se encontró correlación entre las medidas de los vértices de los ángulos superior/inferior y la medida transversal del hiato esofágico. Las medidas entre los vértices de los ángulos superior/inferior, respectivamente, con el tendón central y el ligamento arqueado mediano, presentaron valores torácicos que fueron casi el doble em relación a los abdominales, y fueron estadísticamente significativos. Estas distancias eran más pequeñas en los cadáveres que tenían haces de fibras de colágeno en las márgenes del hiato esofágico. Los paquetes de fibras de colágeno fueron encontrados en $65 \%$ de los 20 márgenes del hiato del esófago. Los márgenes del hiato esofágico fueron formados principalmente por fibras musculares originadas del pilar derecho del diafragma. Los datos anatómicos y morfométricos presentaron valores estadísticamente significativos en relación con: espesor del lado derecho en relación al izquierdo; distancia entre vértice del ángulo superior y el tendón central y distancia entre el vértice del ángulo inferior y el ligamento arqueado mediano.

PALABRAS CLAVE: Diafragma; Unión gastroesofágica; Colágeno; Cadáver; Humanos. 
FILHO, J. J. O.; FILHO, B. H.; REIS, F. P.; FEITOSA, V. L. C. \& ARAGÂO, J. A. Contribution towards the anatomy of the esophageal hiatus and its relationship with the presence of bundles of collagen fibers in its margins. Int. J. Morphol., 30(3):858-865, 2012

\section{REFERENCES}

Allison, P. R. Reflux esophagitis, sliding hiatal hernia and the anatomy of repair. Surg. Gynecol. Obstet., 92(4):419-31, 1951.

Androulakis, J. A.; Skandalakis, J. E. \& Gray, S. W. Contributions to the pathological anatomy of hiatal hernia. J. Med. Assoc. Ga., 55(7) 295-6, 1966.

Basmajian, J. V. Músculo diafragma. In: Basmajian, J. V. Anatomía de Grant. 10a ed. São Paulo, Manole, 1993. p.214.

Botha, G. S. The gastro-oesophageal region in infants; observations on the anatomy, with special reference to the closing mechanism and partial thoracic stomach. Arch. Dis. Child., 33(167):78-94, 1958.

Botros, K. G.; Bondok, A. A.; Gabr, O. M.; el-Eishi, H. I. \& State, F. A. Anatomical variations in the formation of the human oesophageal hiatus. Anat. Anz., 171(3):193-9, 1990.

Bouchet, A. \& Cuilleret, J. Torax. In: Bouchet, A. \& Cuilleret, J. Anatomía descriptiva, topográfica y funcional. Buenos Aires, Panamericana, 1979. pp.70-6.

Bowden, R. E. \& el-Ramli, H. A. The anatomy of the oesophageal hiatus. Br. J. Surg., 54(12):983-9, 1967.

Carey, J. M. \& Hollinshead, J. M. An anatomic study of the esophageal hiatus. Surg. Gynec. Obstet., 100(2):196-200, 1955.

Cecconelo, I.; Zilberstein, B. \& Pinotti, H. W. Tratamento cirúrgico da esofagite de refluxo. In: Pinotti, H. W. Tratado de Clínica Cirúrgica do Aparelho Digestivo. Rio de Janeiro, Atheneu, 1994. pp.374-86.

Collis, J. L. The diaphragm and hiatus hernia. Proc. R. Soc. Med., 59(4):354-6, 1966.

Collis, J. L.; Kelly, T. D. \& Wiley, A. M. Anatomy of the crura of the diaphragm and the surgery of hiatus hernia. Thorax, 9(3):175-89, 1954.

Costa, M. M. B. Sobre a estruturação músculo-facial do hiato esofágico e sua aplicação médico-cirúrgica. Rev. Col. Bras. Cir., 18:109-14, 1991.

Costa, M. M. B. \& Barreto, H. Pilares do diafragma. Rev. Bras. Cien. Morfol., 3(1):47-53, 1986.

Costa, M. M. \& Pires-Neto, M. A. Anatomical investigation of the esophageal and aortic hiatuses: physiologic, clinical and surgical considerations. Anat. Sci. Int., 79(1):21-31, 2004.

Cunningham, D. J. Diafragma. In: Cunninghan, D. J. Anatomía Humana. Barcelona, M. Marin, 1949. pp.490-5.
Dell'Isola, C.; Tucci, G.; Sportelli, G. \& Stroppa, I. Anatomosurgical findings on structure and function of the esophageal hiatus. G. Chir., 10(10):549-52, 1989.

Gardner, E.; Gray, D. J. \& Rahilly, R. O. Parede torácica e mediastino. In: Gardner, E.; Gray, D. J. \& Rahilly, R.O. Anatomía. $4^{\text {a }}$ ed. Rio de Janeiro, Guanabara Koogan, 1988. pp.264-5.

Giordano-Lanza, G. Anatomical and embryological data on the diaphragm, with special reference to the esophageal hiatus. Minerva Med., 64(81):4256-62, 1973.

Girgis, F. G.; Elmalt, A. M. \& Shehata, R. The crura of the diaphragm and their nerve supply. J. Egypt. Med. Assoc., 48(11):798-805, 1965 .

Gray, S. W.; Rowe, J. S. Jr. \& Skandalakis, J. E. Surgical anatomy of the gastroesophageal junction. Am. Surg., 45(9):575-87, 1979.

Groszec, I. Types of the esophageal hiatus in newborns and infants. Folia Morphol. (Warsz), 4(4):337-42, 1984.

Guivarc'h, M. From the normal hiatus to hiatal hernia. Anatomic, topographic, and physiopathologic concepts. Rev. Prat., 23(15):1309-10, 1973.

Hamilton, W. J. Músculo diafragma. In: Hamilton, W. J. Tratado de anatomía humana. $2^{\text {a }}$ ed. Rio de Janeiro, Interamericana, 1882. p.157.

Harrington, S. W. Esophageal hiatal diaphragmatic hernia. Surg. Gynecol. Obstet., 100(3):277-92, 1955.

Juraniec, J. The aortic and esophageal hiatus in the diaphragm of primates. Folia Morphol. (Warsz), 31(2):215-25, 1972.

Khale, W.; Leonhardt, H.; Platzer, W. Tronco: o diafragma. In: Khale, W.; Leonhardt, H. \& Platzer, W. Atlas de anatomía humana. São Paulo, Atheneu, 1995. pp.102-5.

Lataste, J. \& Sulzer, J. Esôfago. Estómago. Duodeno. Diafragma. In: Patel, J. \& Leger, L. Tratado de técnica quirúrgica. $2^{\text {a }}$ ed. Barcelona, Toray-Masson, 1980. pp.611-3.

Listerud, M. B. \& Harkins, H. N. Anatomy of the esophageal hiatus; anatomic studies on two hundred four fresh cadavers. AMA Arch. Surg., 76(5):835-40, 1958.

Low, A. A note on the crura of the diaphragm and the muscle of Treitz. J. Anat. Physiol., 42(Pt 1):93-6, 1907.

Madden, J. L. Anatomic and technical considerations in the treatment of esophageal hiatal hernia. Surg. Gynecol. Obstet., 102(2):187-94, 1956. 
FILHO, J. J. O.; FILHO, B. H.; REIS, F. P.; FEITOSA, V. L. C. \& ARAGÂO, J. A. Contribution towards the anatomy of the esophageal hiatus and its relationship with the presence of bundles of collagen fibers in its margins. Int. J. Morphol., 30(3):858-865, 2012.

Maisonnet, J. \& Coudane, R. Diaphragme. In: Maisonnet, J. \& Coudane, R. Anatomie clinique et operatoire. Paris, G. Doin et Cie, 1950. pp.1425-33.

Mann, C. V.; Greenwood, R. K. \& Ellis, F.H. Jr. The esophagogastric junction. Surg. Gynecol. Obstet., 118:853-62, 1964.

Marchand, P. The anatomy of esophageal hiatus of the diaphragm and the pathogenesis of hiatus herniation. J. Thorac. Surg., 37(1):81-92, 1959.

Moore, K. L. O Abdome. In: Moore, K. L. Anatomía orientada para a clínica. $3^{\mathrm{a}}$ ed. Rio de Janeiro, Guanabara Koogan, 1994. pp.199-203.

Mourot, J. \& Bastian, D. Anatomie chirurgicale de l'oesophage. In: Techniques chirurgicales. Appareil digestif: oesophage. Paris, Techiniques, 1998. 40-170.

Pataro, V. A.; Piombo, H. S.; Suárez, D. Z. \& Acrich, M. W. Anatomic aspects of the esophageal hiatus; distribution of the crura in its formation. J. Int. Coll. Surg., 35(2):154-67, 1961.

Shehata, R. The crura of the diaphragm and their nerve supply. Acta Anat. (Basel) 63(1):49-54, 1966.

Silva, A. L. Hérnias diafragmáticas. In: Silva, A. L. Hérnias. São Paulo, Roca, 1992. pp.337-8.

Skandalakis, J. E.; Gray, S. W. \& Rowe, J. S. Anatomía quirúrgica del diafragma. In: Nyhus, L. M. \& Baker, R. J. El dominio de la cirugía. Buenos Aires, Panamericana, 1986. pp.397-8.

Spalteholz, W. Músculo diafragma. In: Spalteholz, W. Atlas de anatomía humana. $10^{a}$ ed. São Paulo, Roca, 1988. p.119.

Tenière, P.; Scotté, M.; Le Blanc, I. \& Muller, J. M. Traitment chirurgical du reflux gastro-oesophagien de ladulte In: Techniques chirurgicales. Appareil digestif: oesophage. Paris, Techniques, 1994. pp.40-188.

Testut, L. \& Latarjet, A. Músculos del abdomen. In: Testut, L. \& Latarjet, A. Anatomía humana. Barcelona, Salvat Editores, 1979. pp.983-92.

\author{
Correspondence to: \\ Jose Jeová de Oliveira Filho \\ Rua Alda Piassá, 10 \\ Conjunto Leite Neto \\ Bairro Grajeru \\ Aracaju \\ Sergipe \\ BRAZIL
}

Tel: 55 - 79 - 9971-5793

Email: jvvbl@infonet.com.br

Received: 29-10-2011

Accepted: 03-04-2012 